bankruptcy proceeding, either before or after his adjudication..$^{7 x}$ This will aid, in the main, that group of wage-earners whose incomes range between $\$ 5500$ and $\$ 3600$ and thus may have been involuntarily forced into bankruptcy. Exemptions $\mathbf{s}^{72}$ and priorities ${ }^{73}$ are the same as under ordinary bankruptcy.

The lack of specific provision relating to after-acquired indebtedness is likely to lead to difficulty. It would seem that although the later creditors will be able to proceed against any other asset they will not be able to attach the wages of the debtor. From a practical viewpoint this means that a debtor will find it almost impossible to get credit.

The act also lacks a limitation on the number of times the debtor can file thereunder. If there has been no scaling-down either by the plan or by a discharge from his debts, ${ }^{74}$ but merely an extension, there is no limit on the debtor. He can, after finishing one plan, immediately begin another. This lends force to the argument that the court may be utilized as a collection agency.

The debtor has the alternative of choosing to file under Chapter XI dealing with arrangements; ${ }^{75}$ Chapter XIII, however, is far more advantageous to his need, both with respect to costs and to machinery designed for the wageearner's special problems.

It has been suggested that the problems to be solved may be better met by state systems of personal receivership. At least five states, Michigan, Ohio, Wisconsin, Minnesota and Vermont have laws in operation providing this relief under state auspices..$^{76}$ The subject has been adequately treated by Professors Douglas 77 and Garrison. ${ }^{8}$

The necessity for some provision to relieve the conflict between debtor and creditor is evident. Undoubtedly this act will serve a useful purpose in providing a workable solution for the problems of many.

\title{
CORPORATIONS AMENABLE TO THE NEW BANKRUPTCY ACT
}

While section $77^{\mathrm{B}}$ was in force many questions arose as to what kinds of corporations were subject to its provisions. The problem of the amenability of a charitable corporation, ${ }^{2}$ a dissolved corporation, ${ }^{3}$ or a corporation organized

$7 \pi \S 62 \mathrm{r}$.

$72 \S 637$. $73 \S 659(6)$.

74 Pursuant to $\S 66$ т.

r Mich. Comp. Laws (Mason Supp. 1933), \$ई 15364-I to I5364-13; Ohio Gen. Code (Page, Code Service no. 2, I933), § xI728-I; Minn. Stat. (Mason, 1927), § I377; Vt. Laws, I933, No. 3o; Wis. Stat. r937, \& r28.21.

77 Douglas, Wage Earner Bankruptcies-State v. Federal Control, 42 Yale L. J. 59I (r933).

${ }^{78}$ Garrison, Wisconsin's New "Personal Receivership" Law, Wis. L. Rev. 2or ( $\left.{ }_{993} 8\right)$.

${ }^{2} 48$ Stat. gr2 (r934), ir U.S.C.A. \& 207 (r937).

= In re Michigan Sanitarium and Benevolent Ass'n, 20 F. Supp. 979 (Mich. 1937).

${ }^{3}$ In re 4136 Wilcox Ave., 302 U.S. 220 (1938); Hammond, v. Lyon Realty Co., 59 F. (2d) 592 (C.C.A. $4^{\text {th }}$ 1932); Old Fort Improvement Co. v. Lea, 89 F. (2d) 286 (C.C.A. 4th 1937); 
solely to take advantage of the reorganization machinery ${ }^{4}$ occasioned no small amount of litigation. In spite of the provisions of Chapter $\mathrm{X}^{3}$ which supersedes section $77 \mathrm{~B}$ the problem of the amenability of these types of corporations remains perplexing.

Chapter $X$ has changed the definition of a debtor from any corporation which could become a bankrupt under section 4 to any corporation which could be "adjudged a bankrupt." In determining whether or not this definition changes the type of corporations subject to its provisions, there are several relevant sections of the bankruptcy act. "Adjudged a bankrupt" appears in section 4(b) which states that only moneyed, business or manufacturing corporations may be adjudged an involuntary bankrupt. ${ }^{7}$ This is in contrast with section 4 (a) which says that "any person . . . . shall be entitled to the benefits of this Act." Person includes corporations except where otherwise specified. This latter definition was previously used in section $77 \mathrm{~B}$ and Chapter XI9 also retains it. Furthermore section $I(4)$ in its definition of a bankrupt uses the phrase "adjudged a bankrupt" as contrasted with one who can file a petition. ${ }^{\text {Io }}$ But it does not appear that Congress intended to limit Chapter $\mathrm{X}$ to moneyed, business, or manufacturing corporations. The purpose of the change was to obtain uniformity in the meaning of corporation so that a definite meaning would be available. ${ }^{x x}$ (The objective of the change appears to be to abolish the distinction between voluntary and involuntary proceedings.) Since adjudication is a decree that a person is bankrupt ${ }^{x^{2}}$ and a decree of adjudication is entered in voluntary proceedings, ${ }^{x_{3}}$ the phrase "adjudged a bankrupt" refers to the court's powers to enter a decree of adjudication. As such, the words "adjudged a bankrupt" are not limited to involuntary proceedings so that prior opinion which considered charitable corporations amenable to reorganization proceedings is still sound..$^{x}$

Capital Endowment Co. v. Kroeger, 86 F. (2d) 976 (C.C.A. 6th I936); In re 21 1 East Delaware Place Bldg. Corp., 76 F. (2d) 834 (C.C.A. 7 th I935); In re Park Beach Hotel Bldg. Corp., 96 F. (2d) 886 (C.C.A. 7th r938); In re 69th and Crandon Bldg. Corp., 97 F. (2d) 392 (C.C.A. 7th I938); In re International Sugar Feed Co., 23 F. Supp. I97 (Minn. I938).

4 In re Milwaukee Post Building Corp., 95 F. (2d) 948 (C.C.A. 8th I938); In re Loeb Apts., 89 F. (2d) 46 I (C.C.A. 7 th r937); In re Knickerbocker Hotel Company, 8r F. (2d) 98r (C.C.A. 7th r936); In re North Kenmore Bldg. Corp., 8I F. (2d) 656 (C.C.A. $7^{\text {th }}$ I936); In re Francfair, I3 F. Supp. $5 x_{3}$ (N.Y. 1935).

${ }^{5} 5_{2}$ Stat. 883 (I938), Ir U.S.C.A. $\$ 501$ (Supp. r93 $_{93}$ ).

${ }^{6} 5^{2}$ Stat. $88_{3}$ (1938), II U.S.C.A. $\$ 506$ (3) (Supp. 1938 ).

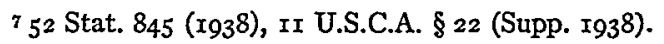

${ }^{8}$ Ibid. $\quad{ }^{9} 52$ Stat. 906 (I938), II U.S.C.A. $\$ 706$ (3) (Supp. r938).

${ }^{10} 52$ Stat. 840 (1938), Ir U.S.C.A. \& I (4) (Supp. I938).

Is See Sen. Report r9I6, 75th Cong. 3d Sess., 23 (r937).

${ }^{12} 5^{2}$ Stat. 840 (I938), II U.S.C.A. § I (2) (Supp. I938).

${ }^{x_{3}} 5_{2}$ Stat. 85 I (1938), Ir U.S.C.A. $\$ 4$ I (g) (Supp. r938).

${ }^{x_{4}}$ See Weinstein, Corporations Amenable to $\$ 77$ B, 83 U. of Pa. L. Rev. 853, 855 (1935); Tondel, Corporations Eligible for Relief under $\$ 77 \mathrm{~B}$, 2 I Minn. L. Rev. I44 (I936). Cf. In re Michigan Sanitarium and Benevolent Ass'n, 20 F. Supp. 979 (Mich. I937). 
Even if Chapter $\mathrm{X}$ is limited to moneyed, business or manufacturing corporations, an alternative basis for allowing a charitable corporation to take advantage of the bankruptcy laws is that it is a business corporation. The word business does not require that the corporation be conducted for profit in the sense that its earnings be divided among its stockholders or members. ${ }^{\text {ts }}$ Any corporation which has elaborate business dealings with the public might be considered a business corporation. ${ }^{16}$

A more difficult issue is whether or not an involuntary petition can be filed against a charitable corporation. In In re Michigan Sanitarium and Benevolent $A s s^{\prime} n^{17}$ the court dismissed the petition filed by creditors on the ground that section $77 \mathrm{~B}$ by its reference to section 4 incorporated in section $77 \mathrm{~B}$ the distinction between voluntary and involuntary proceedings. If Chapter $\mathrm{X}$ by its definition of corporation is limited to moneyed, business or manufacturing corporations, no petition could be filed by or against a charitable corporation. Assuming a voluntary petition can be filed, an involuntary petition should also be allowed. Ordinary bankruptcy involves drastic liquidation proceedings and aims at the termination of an enterprise. Reorganization is essentially a constructive proceeding and contemplates rehabilitation..$^{18}$ It is quite understandable that in view of these different objectives Congress should exempt non-profit corporations from involuntary bankruptcy proceedings while permitting them to voluntarily wind up their affairs. Also the perpetuation of charities will not be jeopardized by such proceedings and the corporation's beneficial activities will not be ended.

Since a charitable corporation could not be subject to an involuntary petition it may be urged that if no plan of reorganization is proposed or confirmed, the court has power to enter an order of liquidation accomplishing indirectly that which it could not do directly. ${ }^{19}$ This argument is not persuasive because it can be argued that if the judge with knowledge of the situation enters an order of liquidation it will be an abuse of his discretion. Moreover it seems that the judge could not enter an order of liquidation because the Congressional policy

${ }^{25}$ See Schuster v. Ohio Farmers' Co-op Milk Association, 6r F. (2d) 337 (C.C.A. 6th 1932); 7 Tulane L. Rev. $45^{8}$ (r932); In re William McKinley Lodge, 4 F. Supp. 280 (N.Y. I933). Contra, In re Dairy Marketing Ass'n of Ft. Wayne, Inc., 8 F. (2d) 626 (D.C. Ind. I925); 74 U. of Pa. L. Rev. 408 (1925).

${ }^{16}$ The word business has been strictly construed by the courts in bankruptcy proceedings. In re Fulton Club, II3 Fed. 997 (D.C. Ga. Ig02); In re Elmsbird Country Club, 50 F. (2d) 238 (D.C.N.Y. r93I); but of. Gibbons v. Ogden, 9 Wheat. (U.S.) 1188 (1824) where Chief Justice Marshall said "Commerce is intercourse."

${ }^{17} 20$ F. Supp. 979 (Mich. 1937); noted 24 Va. L. Rev. 448 (1938).

${ }^{18}$ See Weinstein, op. cit. supra note $\mathrm{I}_{4}$, at 863 .

${ }^{{ }^{2}}{ }_{52}$ Stat. 899 (1938), II U.S.C.A. $\$ 636$ (2) (Supp. 1938). In In re Michigan Sanitarium and Benevolent Ass'n, 20 F. Supp. 979, 985 (Mich. 1937) the court said ' 'If a plan of reorganization is not confirmed, the court may direct the estate to be liquidated. Thus there would be an involuntary bankruptcy proceeding under $\$ 4 \mathrm{~b} \ldots$... Congress did not intend to amend $\S 4$ b by any such oblique and indirect method." 
exempting charitable corporations from involuntary bankruptcy proceedings would be controlling in this situation.

The changes in the Chandler Act have not qualified the position of a dissolved corporation. The issue is still centered on the meaning of "corporation." It is admitted that once Congress has legislated on the subject of dissolved corporations its rights to administer the assets of the corporation are paramount to the state's rights. ${ }^{20}$ Even if the state attempts by its decrees of dissolution to limit the powers of the federal government to take charge of the corporate assets, the legislation would be invalidated. ${ }^{2 x}$ But in the absence of specific legislation on the subject, it is reasonable to assume that state law pertaining to the legislation of dissolved corporations will be suspended only when the jurisdiction of the bankruptcy court is invoked.22

Logically there is a difference between the filing of a debtor and creditor petition, but the courts have not expressly distinguished between them. ${ }^{23}$ The decision in In re 4136 Wilcox Avenue ${ }^{24}$ has recognized that there may be one. This differentiation is now being followed in the seventh circuit. ${ }^{25}$ The filing of a petition for reorganization by a corporation involves a corporate act. But a corporation without the benefit of a statute providing for the winding up of its affairs has no power to use its corporate capacity after the entrance of a decree of dissolution. ${ }^{26}$ Therefore, it was held in In re $4{ }^{1} 36$ Wilcox Avenue, ${ }^{27}$ that a dissolved corporation could not file a voluntary petition for reorganization after the statutory period for winding up its affairs had expired. It can be contended, however, that the incapacity imposed upon the corporation by the

${ }^{20}$ Article r88 clause (4) of the federal Constitution states: "The Congress shall have power .... to establish ... . uniform laws of bankruptcy." All conflicting state law must yield when Congress has exercised its power. International Shoe Co. v. Pinkus, 278 U.S. 26r (r928); Fidelity Trust Co. v. Union Nat'l Bank of Pittsburgh, 3I3 Pa. 467, 485, I69 Atl. 209, 216 (r933); In re Perkins, 3 F. Supp. 697 (N.Y. I933); Union Guardian Trust Co. v. Detroit Creamery Co., 265 Mich. 636, 25 I N.W. 797 (I933); Sturges v. Crowninshield, 4 Wheat. (U.S.) I 22 (18I9). See Miller, Mllinois Business Corporation Act and Bankruptcy Legislation, 29 IIl. L. Rev. 695 (I935). For a general discussion see 48 Yale L. J. 650 (I939).

2x Terral v. Burke Construction Co., 257 U.S. 529 (1922); Pensacola Tel. Co. v. Western Union Tel. Co., 76 U.S. I (1878). See In re Bankshares Corporation of the United States, 50 F. (2d) 94 (C.C.A. $2 d$ I93r) where it was held that directors of a corporation can consent to an act of bankruptcy after appointment of a receiver.

22 Ogden v. Saunders, I2 Wheat. (U.S.) 2 I3 $_{3}$ (I827); In re Watts, Igo U.S. I (IgO2); Johnson v. Star, 287 U.S. 527 (r933); Moore and Levi, Gilbert's Collier on Bankruptcy 2 (4th ed. r937).

${ }_{23}$ Old Fort Improvement Co. v. Lea, 89 F. (2d) 286 (C.C.A. 4th 1937); In re 2II East Delaware Place Bldg. Corp., 76 F. (2d) 834 (C.C.A. 7 th I935). But see In re Vassary Foundry, 293 Fed. 248 (D.C. Mich. I923); Jarow, Voluntary Reorganization of Dissolved Corporations, AI Corp. Reorg. \& Am. Bank. Review 90 (1937).

${ }^{24} 302$ U.S. 120 ( 1938 ).

2s In re Park Beach Hotel Bldg. Corp., 96 F. (2d) 886, 892 (C.C.A. 7th I938).

${ }_{26}$ Oklahoma Gas Co. v. Oklahoma, 273 U.S. 257 (1927); Clinton v. Cooppedge, 2 F. Supp . 935 (Okla. 1933).

${ }^{27} 302$ U.S. 120 (1938). 
state should not bar it from seeking federal relief because the definition of organizations amenable to reorganization includes non-corporate organizations. Because of this it is arguable that Congress did not intend to preclude dissolved corporations from liquidating under federal procedure. But on the other hand it can be said that Congress felt that the state procedure for the administration of the assets of dissolved corporations was adequate just as Congress thinks it desirable to allow the states to administer decedents estates. ${ }^{28}$

It is submitted, however, that in view of the definition of a corporation in Chapter $\mathrm{X}$ as one which could be adjudged a bankrupt a dissolved corporation should be amenable to reorganization by a voluntary petition. If the Supreme Court should permit an involuntary petition to be filed against a dissolved corporation after the statutory period of winding up has expired-the question expressly left open by the Wilcox decision-the dissolved corporation is one which could be adjudged a bankrupt within the literal meaning of the definition of a corporation in Chapter $\mathrm{X}$. As such the manner of instituting the proceedings should be immaterial. The Supreme Court could maintain the position it took in the Wilcox case in spite of the new definition of a corporation by declaring that a dissolved corporation is not a corporation. Another basis for denying relief would be to hold that the filing of a petition by a dissolved corporation is an act of bad faith. ${ }^{29}$

The difficulties of finding a corporate act are eliminated when a petition against a dissolved corporation is filed by the creditors. If the basis of the Wilcox case is that a dissolved corporation has no legal existence after the statutory period of winding up has expired, for the same reason, a similar result should be reached in the case of a petition filed by the creditors. The bankruptcy court has jurisdiction to administer the corporate res as distinguished from the corporate charter. ${ }^{30}$ As such any state laws which would prevent creditors from having the assets of insolvent debtors administered in accordance with the bankruptcy laws would be temporarily suspended. ${ }^{3 x}$ The state by its decree of dissolution cannot prevent the creditors from seeking federal relief. ${ }^{32}$

A dissolved corporation in those states which have statutes giving the corporation limited existence after a decree of dissolution should be able to file a petition for reorganization during this statutory period. ${ }^{33}$ There does not appear to be any urgent reason for denying relief in this situation. The corporation has capacity to sue and thus has legal existence within the scope of the Wilcox case.

${ }^{28} \mathrm{~A}$ petition will not be deemed to be filed in good faith if a prior proceeding is pending in any court and it appears that the interests of creditors and stockholders would be best subserved in such prior proceeding, $5_{2}^{2}$ Stat. 887 ( $x_{93} 8$ ), II U.S.C.A. $\$ 546$ (4) (Supp. I938).

29 Note 28 supra.

30 Glenn, Liquidation $245 \mathrm{ff}$. (I935).

${ }^{3}$ Note 20 supre.

${ }^{32}$ Hammond v. Lyon Realty Co., 59 F. (2d) 592 (C.C.A. 4th x932); In re $21 x$ East Delaware Place Bldg. Corp., 76 F. (2d) 834 (C.C.A. 7 th I935); In re Storck Lumber Co., Ir 4 Fed. 360 (D.C. Md. Ig02); In re Munger Vehicle Tire Co., I59 Fed. 901 (C.C.A. 2d Igo8).

${ }_{33}$ See In re International Sugar Feed Co., 23 F. Supp. I97 (Minn. I938). 
Even if the basis of the Wilcox case is that a dissolved corporation is not a corporation within the intent of the act, the decision can be limited to dissolved corporations which have no legal existence under the state laws which created them.

It may be urged, however, that if Congress deemed it desirable to allow state law to control the winding up of the affairs of a dissolved corporation, the fact that the state has given the corporation limited life would not be sufficient to give the bankruptcy court jurisdiction. Furthermore it seems that all parties could be protected in the dissolution proceedings, so that the petition would be construed as one not filed in good faith. ${ }^{34}$

The issue raised by a corporation organized solely to take advantage of the reorganization laws is whether it can be considered bad faith on the part of the debtor to incorporate so that he could evade other provisions of the bankruptcy act. ${ }^{35}$ The device of forming a corporation to take advantage of the reorganization laws was resorted to almost entirely by individuals who issued bonds on their real estate secured by a mortgage since relief under section $74^{36}$ was inadequate. Because section 74 did not allow a scaling down of the secured indebtedness and the problems of the individual debtor were analogous to that of a corporation, the courts split on the issue of whether the individual could incorporate his real estate holdings. ${ }^{37}$ The decisions which disapproved of this practice and held that the petition was filed in bad faith can be explained by the fact that the petitioners did not have any substantial interest in the reorganization proceedings, and were attempting to gain an unwarranted advantage over their several creditors..$^{38}$ The practice of incorporating one's holdings to evade one Federal law and take advantage of another may have become moot by the insertion of Chapter XII39 which liberalizes section 74 . Chapter XII deals exclusively with arrangement by debtors who are the legal or equitable

34 Note 28 supra.

${ }^{35}$ See In re Loeb Apts. 89 F. (2d) $46 x$ (C.C.A. 7 th 1937 ) where the debtor originally filed a petition under $\$ 74$ which was dismissed because of lack of jurisdiction.

${ }^{36} 47$ Stat. ${ }^{4} 467$ (I933), II U.S.C.A. § 201 (1937). For a criticism of $\S 74$ see Levi and Moore, Bankruptcy and Reorganization, 5 Univ. Chi. L. Rev. 244 ff. (1938). See In re Iversen, 85 F. (2d) I59 (C.C.A. 7 th I936) where it was held that a secured creditor cannot be forced to submit to a reduction in note of accrued interest, note, 5o Harv. L. Rev. $35^{\circ}$ (1936). For a discussion on $\S 74$ see Russell, Section 74 and $77 \mathrm{~B}$ of the Bankruptcy Act, $x$ John Marshall L. Q. 45 (I936).

${ }^{37}$ In re Loeb Apts., 89 F. (2d) 46 I (C.C.A. 7th I937) (good faith); In re Milwaukee Post Building Corp., 95 F. (2d) 948 (C.C.A. 8th r938) (bad faith); In re North Kenmore Bldg. Corp., 8I F. (2d) 656 (C.C.A. 7th I936) (bad faith). Cf. In re Collins, 75 F. (2d) 62 (C.C.A. 8th 1934) where it was held that a corporation could not transfer its assets to its principal stockholder to come within the provisions of $\S 74$.

${ }^{38}$ In re North Kenmore Bldg. Corporation, 8x F. (2d) 656 (C.C.A. 7th 1936) (82\% of the bondholders disapproved); In re Francfair, $x_{3}$ F. Supp. 5r3 (N.Y. $x_{935}$ ) (attempt to liquidate one of several pieces of property).

${ }^{39} 5^{2}$ Stat. 9r6 (1938), тा U.S.C.A. § 80г (Supp. I938). 
owners of real property or a chattel real which is security for any debt. There are no other limitations upon the class of those who may file under Chapter $\mathrm{XII}$, except that the arrangements are primarily for secured creditors. $4^{\circ}$ Since the requirements of Chapter XII appear on the whole to be less stringent than those of Chapter $X$ it is very likely that the problem in the future will be the converse of the present one in that corporations will transfer their properties to individuals and attempt to proceed under Chapter XII.4r

Even though Chapter XII was expressly inserted in the bankruptcy act to remedy the plight of the individual debtor with real estate indebtedness, the debtor may still want to seek relief under Chapter $\mathrm{X}$. Insofar as the cases under $77 \mathrm{~B}$ held petitions as not filed in good faith when filed by corporations organized for that purpose, the failure to specifically outlaw such practice in the good faith section of Chapter X may mean that the practice is not disapproved. Although good faith is not defined, a minimum criterion has been set up so that good faith does not exist in the following fact situations. (I) If the creditors have acquired their claims for the purpose of instituting proceedings; (2) if adequate relief would be obtainable under Chapter XI; (3) if it is unreasonable to expect that a plan of reorganization can be effected; (4) if a prior proceeding is pending in any court and it appears that the interests of creditors and stockholders will be best subserved in such prior proceedings.42 Except for the second these statutory enactments represent prior case law under section $77 \mathrm{~B}$ which did not provide any criteria for determining good faith. ${ }^{43}$ Therefore, it can be contended that Congress did not intend to include under the concept of bad faith a corporation organized solely to take advantage of Chapter $\mathrm{X}$ as decisions on the instant point had been rendered prior to the drafting of the Chandler Act.

\section{SOME ASPECTS OF THIRD PARTY BENEFICIARY CONTRACTS IN IILINOIS}

In England, the third party beneficiary of a contract occupies a very definite, even if not an advantageous position. He cannot bring an action against the

${ }^{40}$ See $5_{2}$ Stat. 918 (1938), II U.S.C.A. $\$ 806$ (I), (6) (Supp. I938).

${ }_{41}$ Chapter XII does not have any good faith requirement. Furthermore there are no provisions which provide for the intervention of the Securities Exchange Commission. Also many of the disclosure provisions of Chapter $\mathrm{X}$ to safeguard the creditors in the formulation of a plan are absent. But Chapter $\mathrm{X}$ has more liberal provisions for the allowance of fees. Chapter XII is also speculative as to what may be deemed to be an interest in real property. Unsecured creditors can only be brought into the proceedings indirectly.

${ }_{42} 5_{2}$ Stat. 887 (1938), iI U.S.C.A. 8546 (Supp. I938).

${ }^{43}$ In re Philadelphia Rapid Transit Co., 8 F. Supp. 5 I (1934) aff'd 73 F. (2d) ro22 (C.C.A. 3d 1934) (buying up bonds); In re Electric Public Service Co., 9 F. Supp. 128 (Del. 1934) (prior proceedings upheld); Provident Mut. Life Ins. Co. v. University Ev. Lutheran Church, 9o F. (2d) 992 (C.C.A. 9th 1937) (no plan). See Gerdes, "Good Faith," in the Initiation of Proceedings under $\S 77 \mathrm{~B}$ of the Bankruptcy Act, 23 Geo. L. J. 4I8 (I935). Note, Judicial Discretion of Petitions Filed under $\S 77$ B, 48 Harv. L. Rev. 283 (1934). 